\title{
Indicators for the economic dimension of sustainable agriculture in the European Union
}

Gábor Valkó Over the past decade, the concept of sustainaHungarian Central Statistical ble development became inevitable on asOffice sessing economic, social, and environmental

Budapest, Hungary processes. Although the concept of sustainable E-mail: Gabor.Valko@ksh.hu agriculture also includes environmental and so-

Mária Fekete-Farkas

Szent István University

Gödöllő, Hungary

E-mail:

Farkasne.Fekete.Maria@gtk.szie.hu

Ildikó Kovács

Budapest Business School, University of Applied Sciences

Budapest, Hungary

E-mail: Kovacs.Ildiko@uni-bge.hu cial aspects, the economic facet is still important for decision makers and researchers because of the increasing needs of the worldwide growing population. Moreover, the economic dimension of agriculture is also important because agriculture viability and compatibility are key determinants of its future. Consequently, we compiled an indicator system on the agricultural sustainability based on statistical data, which describes four dimensions of agriculture sustainability (food supply, environment, economy, and society). The indicator system consists of 44 indicators and can serve as a basis for developing composite indicators. Based on the indicator system and the composite indicators of the performance of EU countries, this study analyses economic dimension of EU agriculture (12 indicators). The results allow spatial comparisons and monitoring de-

Keywords: velopment over time. The performance of sustainability, Hungary in terms of the economic dimension agriculture, of sustainable agriculture is then analysed in composite indicators comparison with its regional competitors.

\section{Introduction}

The concept of sustainable development was defined by the Brundtland report (Our Common Future), in 1987. Complementary to the Lisbon agenda, the EU adopted an equally ambitious Strategy for Sustainable Development (SDS) at the Gothenburg Summit, in 2001, which was to underpin all EU policies and actions. However, a number of unsustainable trends have worsened since 2001.

Regional Statistics, Vol. 7. No.1. 2017: 179-196; DOI: 10.15196/RS07110 
Agriculture is a special branch of the economy. Agricultural production is a nature-related activity, and has significant impact on the state of the environment, while also being an integral part of rural life. On one hand, it has remarkable influence on rural areas and, on the other hand, it is dependent on them in many aspects.

Agricultural production is multi-purpose as there are economic, environmental, and social roles of agriculture (OECD 2001, Boody et al. 2005, Rossing et al. 2007, Feher-Beke Lisanyi 2013, Królczyk et al. 2014, Huang et al. 2015). The main task of agriculture is food and fibre production, which describes both its productive or economic functions. Over the past decades, new tasks related to the economic function came to the fore, including controversial biofuel production (Fekete-Farkas et al. 2011, Popp et al. 2014). The profitability and viability of agricultural activities is vital. To achieve this, the production efficiency and competitiveness of the entire sector are essential.

Earth's growing population requires a large amount of surplus production of food. As such, the increase of utilized agricultural areas and/or of production efficiency are inevitable if consumption patterns remain unchanged. Therefore, the efficiency and economic dimension of agriculture sustainability are emphasised compared to the sustainability of other economic sectors. Although consumption is generally harmful to the environment (Kovács 2016), production and consumption of food are inevitable for life.

\section{Indicator system of sustainable agriculture}

A reliable indicator system describing sustainability becomes a pronounced requirement of decision-makers. Moreover, there is also an intensified expectation from the public to gain information on social and economic processes in terms of sustainability. Numerous organizations and scientific institutions have developed indicators and indicator systems that measure the performance of agriculture in terms of sustainability (e.g. MAFF 2000, INEA 2002, Valkó-Fekete-Farkas 2014). However, they are not fully adapted to Hungarian and European Union agriculture, most covering national context and not allowing spatial comparisons. These sets of indicators including numerous indicators do not provide a comprehensive picture. Consequently, there is a need for an indicator system that provides easily understandable information even on complicated, multi-dimensional issues such as sustainability. Besides, agriculture-related indicators are underrepresented in the indicator systems for sustainable development created by the United Nations and Eurostat.

There is a need for an indicator system that describes agricultural production of EU member states in terms of sustainability and is also capable of evaluating certain sustainability areas, thus presenting results, based on composite indicators, that are easy to communicate. This type of indicator system has not yet been developed for

Regional Statistics, Vol. 7. No.1. 2017: 179-196; DOI: 10.15196/RS071 10 
the EU. The indicator system presented in this study is based on statistical data and can serve as a basis for producing composite indicators describing sustainability domains. It can also compare the sustainability performance of individual countries and monitor development over time; however; it obscures regional differences within a country. The indicator system has been validated by Hungarian and international experts with expertise in the sustainability of agriculture by filling in questionnaire aiming at the determination of the weights used for the development of composite indicators.

The theoretical framework of the indicators of sustainable agriculture in this study was built on a definition of sustainable agriculture from synthesising literature sources. The sources for the creation of the definition include: EU 2012, Farkasné Fekete et al. 2004, Kirchmann-Thorvaldsson 2000, National Research Council 2010, OECD 2001, RISE 2016, SARE 1997, Smith-McDonald 1998, Takácsné György et al. 2008, USDA 1999, Valkó-Farkasné Fekete 2014, Van Cauwenbergh et al. 2007.

The four points of the synthesised definition identified the domains of the indicator system, which are as follows:

- production of good quality, safe, and healthy foods; satisfaction of needs-food supply;

- conservation of natural resources, protection of the environment, creation of animal welfare-environment;

- efficiency, competitiveness, economic viability, ensuring profitabilityeconomy;

- improving the quality of life in rural areas, social justice, and development of attractive rural landscape-society.

\section{Methodology of developing composite indicators for the sustainability of agriculture'}

For the design and execution of the research, the 'Handbook on Constructing Composite Indicators', released by the OECD (2008), was used. According to the theoretical framework, 44 indicators were chosen and elaborated for the four domains. However, in this study, only the domain Economy is analysed, with its 12 indicators. Only the indicators for which data are available for EU member countries during 2000-2012 were selected. The data source for the Economy was the Eurostat database. Nearly 15 thousand data items were gathered for the entire indicator system, followed by data checking and editing, as well as the input of missing data. All phases of the process were carried out in a planned way, the most appropriate imputation method for the particular data type being used. Through the phas-

\footnotetext{
${ }^{1}$ The research that serves as a basis for this article was carried out during 2013-2015 by Gábor Valkó, and the
} results were compiled in his PhD dissertation (Valkó 2015).

Regional Statistics, Vol. 7. No.1. 2017: 179-196; DOI: 10.15196/RS071 10 
es of indicators' selection and collection of basic data, the quality requirements developed by Eurostat and OECD were followed (Eurostat 2011, OECD 2012). The time series for 2000 to 2010 were used for analysis. An examination of the relationship between indicators using correlation matrices was carried out prior to finalizing the indicator system. The correlation matrices were compiled using the Pearson correlation test on the 2010 data, separately for the four domains and for the entire indicator set. The relationships between individual indicators can be explained. However, the number and strength of these relationships are not such that would reduce the reliability of the indicator system. Based on correlation analysis, the inclusion of each indicator in the system is reasonable (Table 2 includes the indicators for the domain Economy).

To develop composite indicators, the normalization of indicator system data was carried out using the min-max method, with the application of the following formula (OECD, 2008):

$$
I_{q c}^{t}=\frac{x_{g c}^{t}-\min _{t e T} \min _{c}\left(x_{q}^{t}\right)}{\max _{t \in T} \max _{c}\left(x_{q}^{t}\right)-\min _{t \in T} \min _{c}\left(x_{q}^{t}\right)},
$$

where

$$
\begin{aligned}
x_{q c}^{t} & =\text { value of indicator } q \text { for country } c \text { and year } t \\
I_{q c}^{t} & =\text { normalized value of indicator } q \text { for country } c \text { and year } t .
\end{aligned}
$$

The weights required for the calculation of the composite indices were determined by expert opinion. In the literature (OECD 2008), this procedure is referred to as the budget allocation process (BAP). During this process, experts distribute 100 points for the indicators according to their importance, in terms of the target determined by the theoretical framework of the indicator system. Determination of weights is complex, and it is difficult to make an informed decision because of the too many circumstances to be considered and the limited information. For this reason, the experts who had difficulties in the distribution of 100 points were offered to determine the rank of indicators in terms of their contributions to the sustainability of agriculture. The opinion of the experts giving ranks was processed by converting the ranks to weights using the following formula:

$$
w_{i}=\frac{r_{\max }-r_{i}+1}{\sum_{i=1}^{n} r_{i}},
$$

where

$$
\begin{aligned}
& W_{i}=\text { weight of indicator } I ; \\
& r_{i}=\text { rank of indicator } i .
\end{aligned}
$$

Regional Statistics, Vol. 7. No.1. 2017: 179-196; DOI: 10.15196/RS07110 
The aggregation of indicators was performed using linear aggregation by adding the normalized and weighted values of the indicators according to the formula (OECD, 2008):

$$
K I_{c}=\sum_{q=1}^{Q} w_{q} I_{q c}
$$

where

$$
\begin{aligned}
& \sum_{q} W_{q}=1 \text { and } 0 \leq W_{q} \leq 1 \text { for all } q=1, \ldots, Q \text { and } c=1, \ldots, M ; \\
& K I_{c}=\text { value of composite indicator for country } c \\
& W_{q}=\text { weight of indicator } q \text {; } \\
& I_{q c}=\text { value of indicator } q \text { for country } c .
\end{aligned}
$$

The weight system of the composite indicators was developed using the results of an expert survey. The survey research was carried out between 28 October 2014 and 6 January 2015. Questionnaires were sent to a total of 102 experts (including international experts), with expertise in sustainability of agriculture. Of these, 60 experts returned the questionnaire, representing a return rate of 59\% (Table 1); 65\% of the respondent experts held at least a $\mathrm{PhD}$ degree and the rest at least an MSc.

Table 1

\section{Number of questionnaires sent out and received during the expert survey}

\begin{tabular}{l|c|c|c}
\hline \multicolumn{1}{c|}{ Expert } & $\begin{array}{c}\text { Number of } \\
\text { questionnaires sent }\end{array}$ & $\begin{array}{c}\text { Number of ques- } \\
\text { tionnaires received }\end{array}$ & Return rate, \% \\
\hline Hungarian expert & 60 & 41 & 68.3 \\
International expert & 25 & 12 & 48.0 \\
$\begin{array}{l}\text { Expert from an international or- } \\
\text { ganization (outside Hungary) }\end{array}$ & 17 & 7 & 41.2 \\
Total & 102 & 60 & 58.8
\end{tabular}

Source: own research.

When compiling a composite indicator system, a number of subjective decisions have to be made, which may substantially influence the composite indicator values. Therefore, the robustness and reliability of the composite indicators were measured using sensitivity analyses for the following areas: compilation of indicator system, type of weighting system, and expert selection. The values of the key composite indicator for the sustainability of agriculture calculated with modified conditions were then compared with the results from the original method. Based on the results, only the selection of the type of weighting system influenced significantly the values of composite indicators.

Regional Statistics, Vol. 7. No.1. 2017: 179-196; DOI: 10.15196/RS07110 


\section{Research results}

\section{Indicator system of sustainable agriculture}

The established system of indicators for the economic dimension is shown in Table 2. Twelve indicators were chosen of the indicator system and were grouped in two sub-groups so that the importance of the indicators could be assessed more easily by the experts.

Table 2

Indicators of domain economy of the indicator system for sustainable agriculture and their weights

\begin{tabular}{|c|c|c|c|c|}
\hline Theme & Indicator & Unit & Goal* & Weight \\
\hline \multicolumn{5}{|c|}{ Efficiency, competitiveness } \\
\hline Resource use & $\begin{array}{l}\text { Output per intermediate consump- } \\
\text { tion in agriculture }\end{array}$ & - & + & 19.3 \\
\hline $\begin{array}{l}\text { Efficiency of land } \\
\text { use }\end{array}$ & $\begin{array}{l}\text { Gross value added per hectare of uti- } \\
\text { lized agricultural area }\end{array}$ & EUR/ha & + & 21.8 \\
\hline Labour productivity & $\begin{array}{l}\text { Gross value added per labour input in } \\
\text { agriculture }\end{array}$ & $\begin{array}{c}1000 \text { EUR/ } \\
\text { annual work unit }\end{array}$ & + & 20.5 \\
\hline $\begin{array}{l}\text { Competitiveness in } \\
\text { foreign trade }\end{array}$ & $\begin{array}{l}\text { Ratio of exports and imports of agri- } \\
\text { cultural products }\end{array}$ & - & + & 14.2 \\
\hline Yields & Yields of cereals & $100 \mathrm{~kg} / \mathrm{ha}$ & + & 13.7 \\
\hline $\begin{array}{l}\text { Utilization of agri- } \\
\text { cultural land area }\end{array}$ & $\begin{array}{l}\text { Share of unutilized agricultural area as } \\
\text { a percentage of total agricultural area }\end{array}$ & $\%$ & - & 10.6 \\
\hline \multicolumn{5}{|c|}{ Economic viability, profitability } \\
\hline $\begin{array}{l}\text { Replacement of } \\
\text { means of produc- } \\
\text { tion }\end{array}$ & $\begin{array}{l}\text { Gross fixed capital formation per } \\
\text { consumption of fixed capital in the } \\
\text { agriculture }\end{array}$ & EUR & + & 15.3 \\
\hline $\begin{array}{l}\text { Diversification of } \\
\text { production }\end{array}$ & $\begin{array}{l}\text { Standard output of farms with non- } \\
\text { agricultural activities as percentage of } \\
\text { total standard output }\end{array}$ & $\%$ & + & 15.7 \\
\hline $\begin{array}{l}\text { Research and devel- } \\
\text { opment }\end{array}$ & $\begin{array}{l}\text { Research and development in agricul- } \\
\text { ture EUR 1,000 of gross value added }\end{array}$ & EUR & + & 17.3 \\
\hline $\begin{array}{l}\text { Age composition of } \\
\text { farmers }\end{array}$ & $\begin{array}{l}\text { Ratio between percentage of farmers } \\
\text { below } 35 \text { and } 65 \text { or older in terms of } \\
\text { standard output }\end{array}$ & - & + & 13.5 \\
\hline Agricultural income & Agricultural income - indicator ' $A$ ' & $2005=100$ & + & 22.4 \\
\hline Subsidy dependency & $\begin{array}{l}\text { Agricultural subsidies in percentage } \\
\text { of gross value added }\end{array}$ & $\%$ & - & 15.8 \\
\hline
\end{tabular}




\section{Indicator system of the economic dimension of sustainable agriculture}

Within the sub domain 'Efficiency and competitiveness', the largest weights were assigned to the indicators of efficiency of land use, labour productivity, and resource use (Table 2). The utilization of agricultural land area was, however, considered the least important one by the experts. The standard deviation of the evaluation of each indicator for labour productivity was relatively high (10.8), while in the case of the indicators' 'yields' (5.6) and 'utilization of agricultural land' (5.7), it was rather low.

The index of agricultural income was assessed as the most important from the sub domain 'Economic viability and profitability' (Table 2). There was a relatively high evaluation of the indicator 'R\&D', while the lowest average weight was assigned to the 'age composition of farmers'. The standard deviation of each indicator was relatively low, the highest being the 'diversification of production' (9.1), while the lowest was R\&D (6.0).

The sub domain 'Economic viability and profitability' was considered slightly more important (52.2) than 'Efficiency and competitiveness' (47.8) by the experts. A high proportion of experts $(37.9 \%)$ assigned the same importance to both areas. The indices of the sub-themes had a moderate standard deviation (13.0).

\section{Values of the indices in the domain 'Economy'}

The composite index for the sub domain 'Efficiency, competitiveness' within 'Economy' is extremely high in the Netherlands compared to other member countries in 2010 (Figure 1). The Netherlands is followed by Spain and France, while Latvia, Slovakia, and Estonia had the least efficient agriculture in the EU in 2010 on the basis of index values. Hungary's performance is similar to that of Poland and Lithuania, but behind the EU average regarding the level of efficiency and competitiveness on the basis of 2010 figures. The Netherlands reached the highest values for land use efficiency and labour productivity, and the second highest index for foreign trade competitiveness and yields. Latvia, as a counterpoint to the Netherlands, had the lowest values for land use and work efficiency indicators.

The EU as a whole registered a $12 \%$ increase in the efficiency and competitiveness of agriculture between 2000 and 2010 on the basis of the composite indicator. The highest growths were detected in Finland (175\%), Cyprus (80\%), Latvia (78\%), and Poland (50\%), while the largest decrease took place in Ireland $(27 \%)$ and Hungary $(7 \%)$.

Regional Statistics, Vol. 7. No.1. 2017: 179-196; DOI: 10.15196/RS07110 
Values of index components for 'Efficiency, competitiveness'

Figure 1 in EU member states, 2010

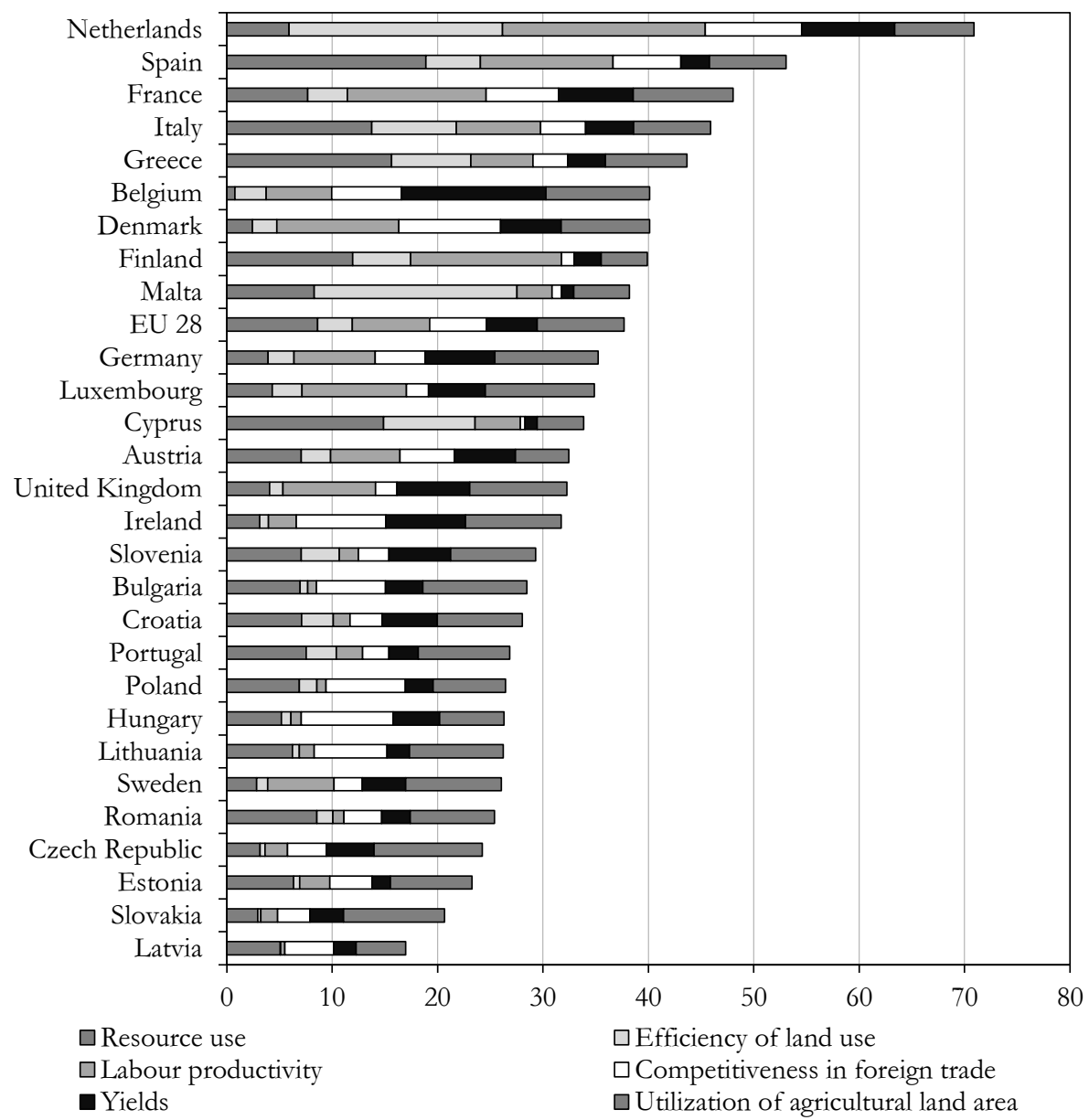

Source: own calculation based on Eurostat data (Eurostat 2014).

According to the indicators for 'Economic viability, profitability' for 2010, Belgium reached the highest values, followed by Germany and Austria, while the lowest values were found for Ireland, the Czech Republic, and Slovakia (Figure 2). Belgium had the highest score in the EU in the areas of research and development and level of farm income, while for the diversification of farming only the Czech Republic had a lower value. Ireland performed generally poorly, except for diversification. 
Values of index components for 'Economic viability, profitability'

Figure 2 in EU member states, 2010

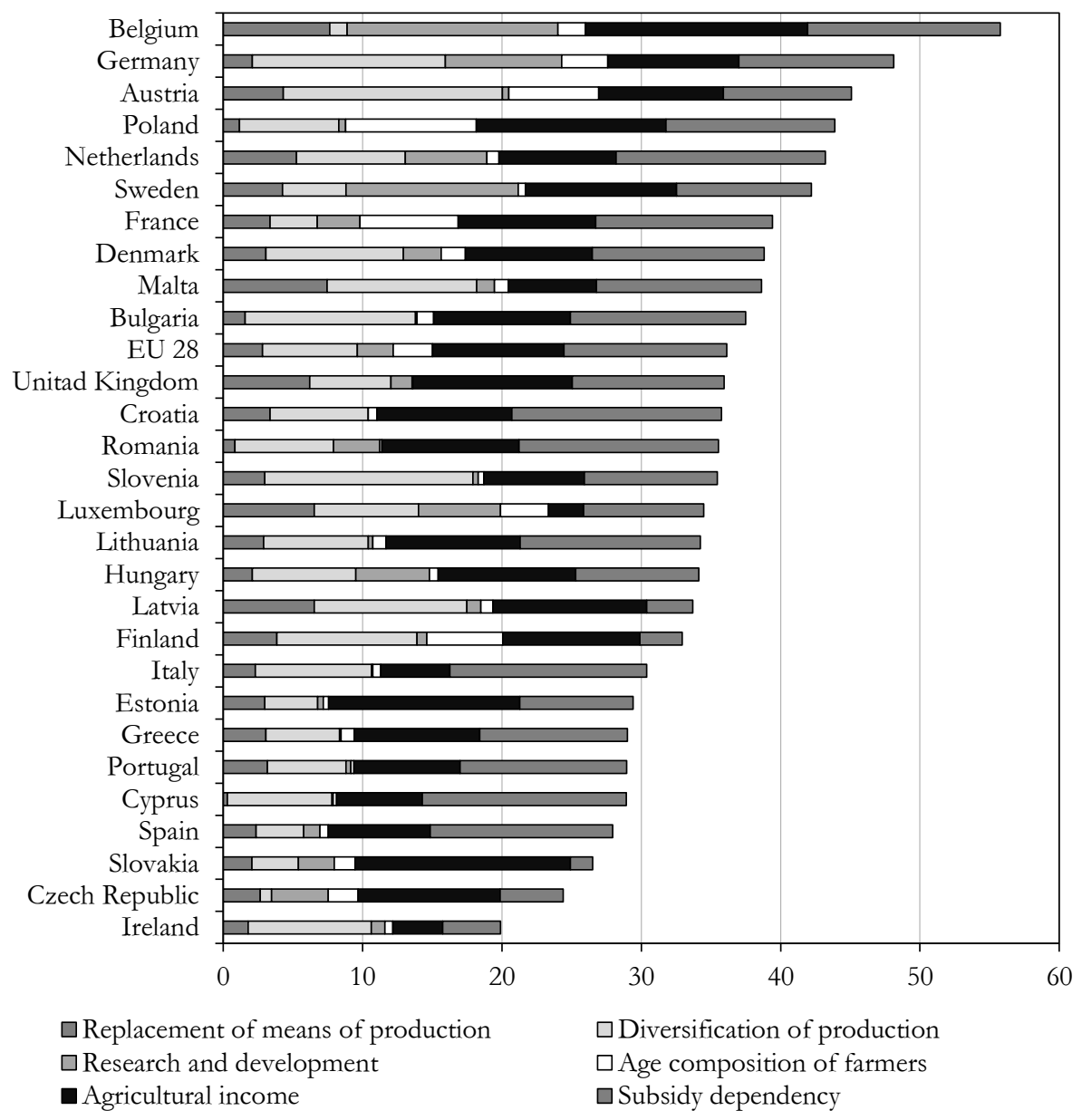

Source: own calculation based on Eurostat data (Eurostat 2014).

The composite indicator for the sub domain 'Economic viability, profitability' increased most in Romania (46\%), Poland (35\%), and Belgium (33\%) between 2000 and 2010, while decreases were registered in Ireland (42\%), Italy (28\%), and Bulgaria (24\%). The growth in Hungary (10\%) was above the EU average (4\%).

The composite index of sustainable agriculture 'Economy' had the highest values in the Netherlands and Belgium in 2010, and the lowest in Ireland, the Czech Republic, and Slovakia (Figure 3). Poland is the only country of Central and Eastern Europe that had a higher indicator than the EU average. The composite index for -

Regional Statistics, Vol. 7. No.1. 2017: 179-196; DOI: 10.15196/RS07110 
'Economy' is shown in Figure 4. The two leading countries were the Netherlands, with the most efficient agricultural production in the EU, and Belgium, with the most viable and profitable agriculture in 2010.

Figure 3

Values of the index for the Economic dimension in EU member states, 2010

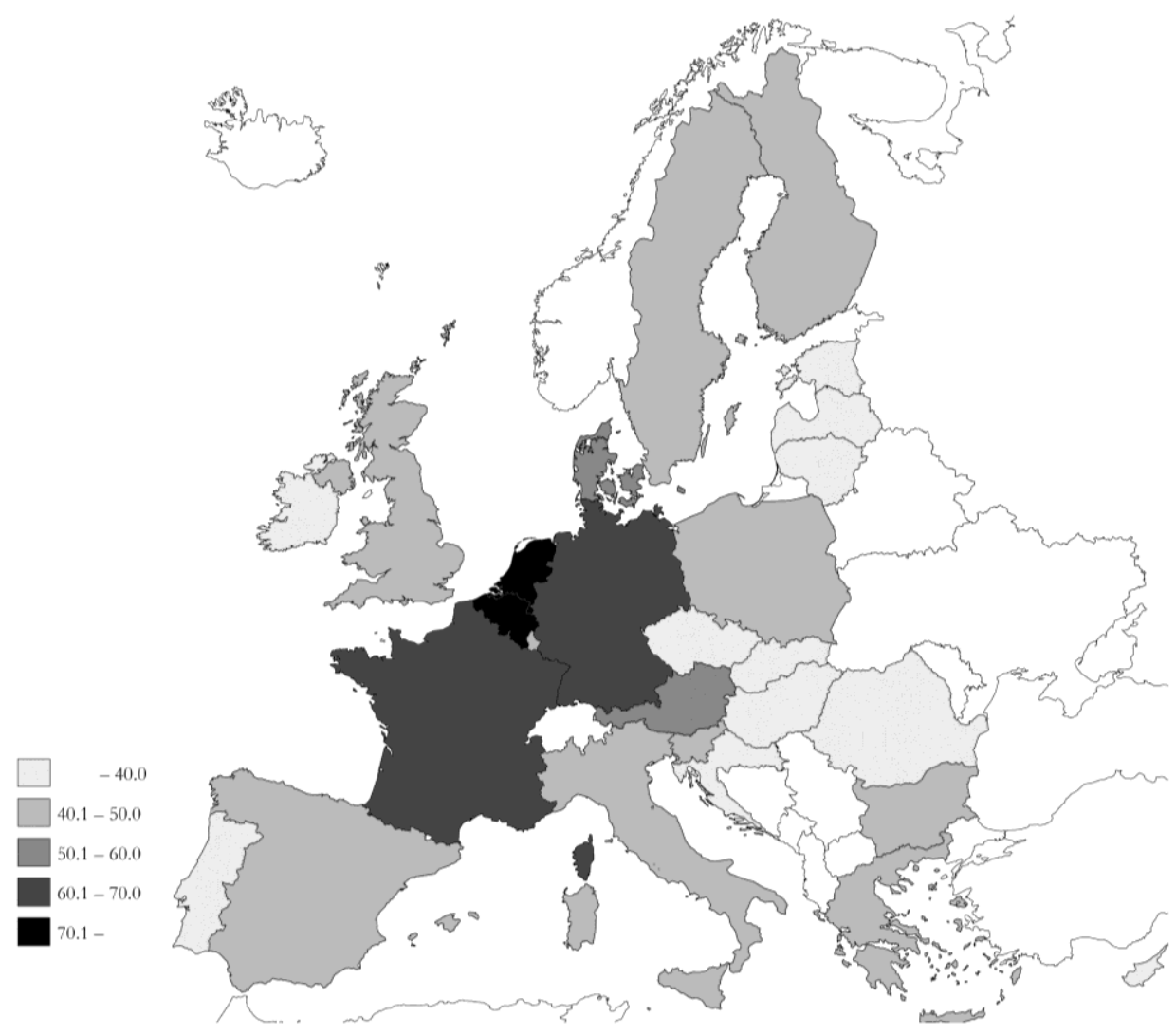

Source: own calculation based on Eurostat data (Eurostat 2014). 
Values of index components for 'Economy' in EU member states, 2010

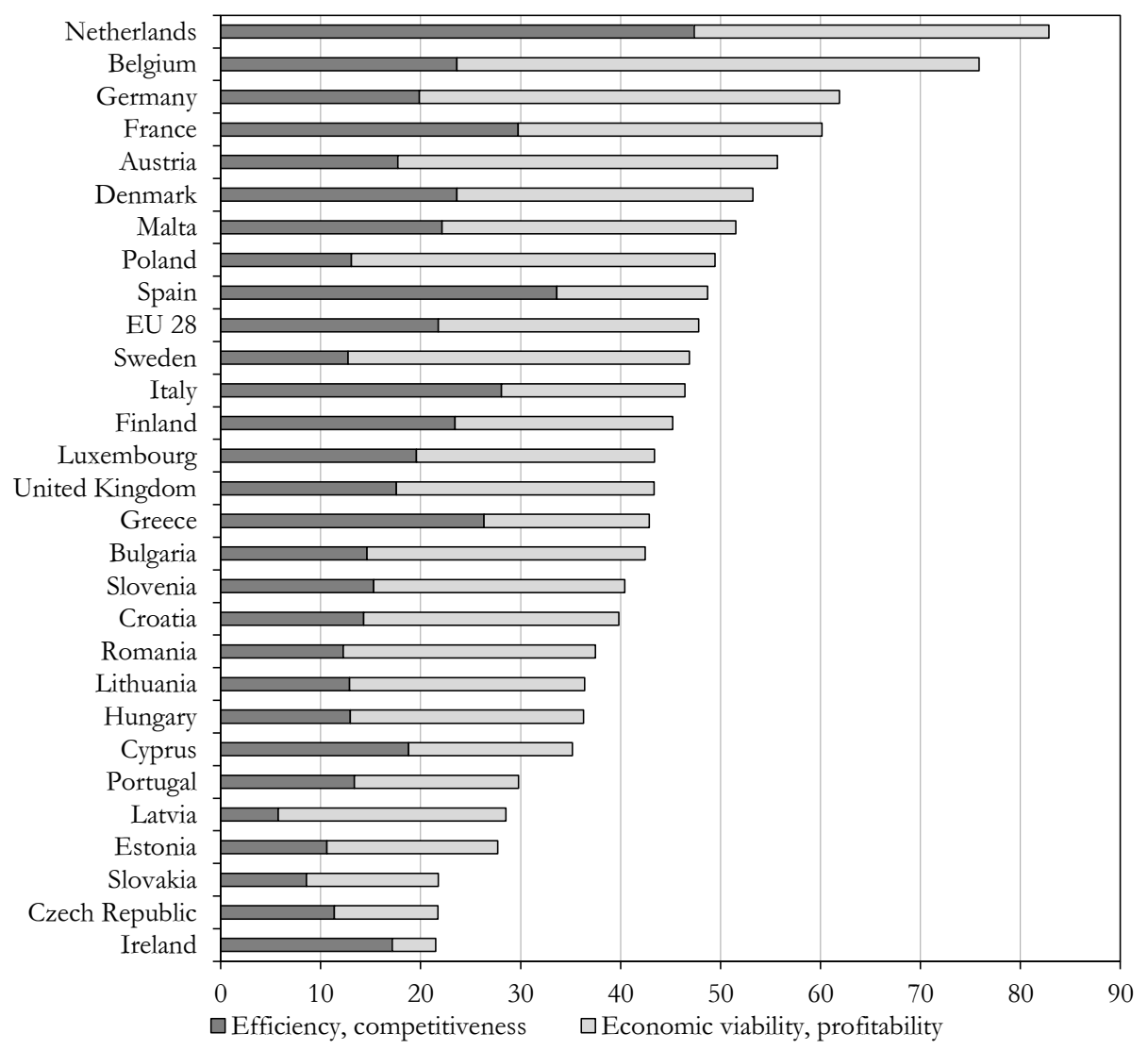

Source: own calculation based on Eurostat data (Eurostat 2014).

The composite index of the economic dimension achieved the highest growth in Romania (84\%), Poland (80\%), and Finland $(71 \%)$, while it decreased most in Ireland (57\%) and Italy (21\%) from 2000 to 2010 . The increase in Hungary was 8\%, slightly below the average growth of the EU (11\%). The 2010 values of the index and the relative changes in their values compared to 2000 are displayed in Figure 5.

Regional Statistics, Vol. 7. No.1. 2017: 179-196; DOI: 10.15196/RS07110 
Values of the index for 'Economy' and the rate of change compared to 2000 figures in $\mathrm{EU}$ member countries, 2010

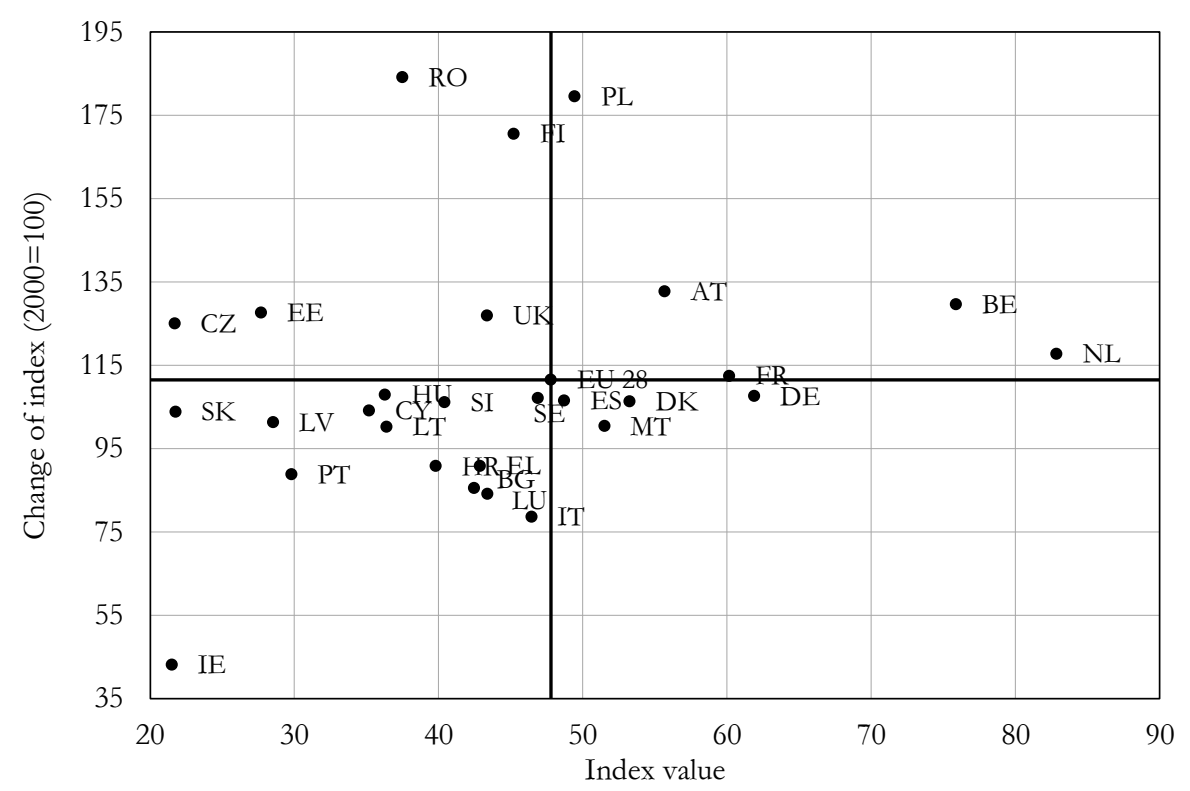

Source: own calculation based on Eurostat data (Eurostat 2014).

\section{Values of the domain 'Economy' for Hungary}

Within the domain 'Economy', the indicator measuring efficiency and competitiveness for Hungary was significantly below the EU average in 2010 (Figure 6). The largest backlog was observed in work productivity, efficiency of land use, and resource use, while foreign trade competitiveness performed above the EU average. The composite indicator value slightly declined in Hungary between 2000 and 2010, while the EU average showed an increase. The deterioration of its relative position is primarily a result of the negative trend experienced in the field of foreign trade competitiveness and farmland utilization, while in the area of resource use, relative improvement occurred compared to the EU average.

The Hungarian index for the sub domain 'Economic viability, ensuring profitability' was below the EU average (Figure 7) for 2010. Hungarian agriculture showed a significant shortfall compared to the EU average for the age composition of farmers, supply of production equipment, and aid dependency. The indicator for R\&D was, however, above the EU average. The changes experienced in Hungary between 2000 and 2010 do not deviate significantly from the EU average of the individual indices in direction and degree. The composite index moved closer to the EU average, over the 11 years under analysis, but it was still below it in 2010 .

Regional Statistics, Vol. 7. No.1. 2017: 179-196; DOI: 10.15196/RS07110 
Values of indicators for 'Efficiency, competitiveness'

Figure 6 in Hungary compared to the EU average, 2010

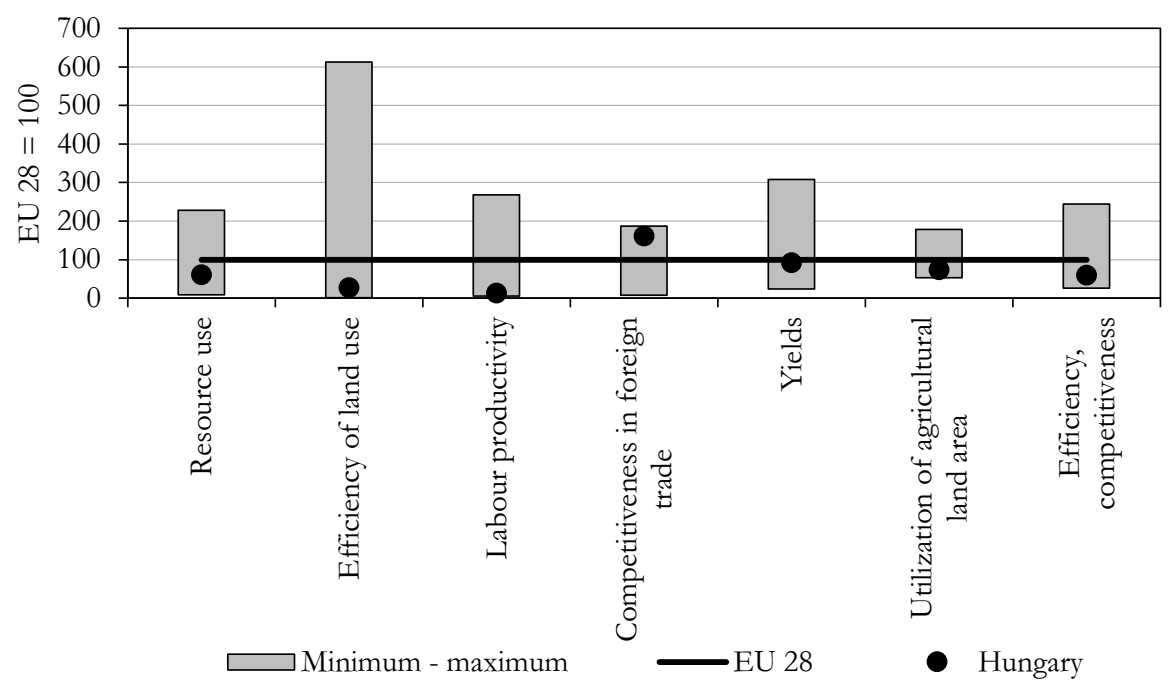

Source: own calculation based on Eurostat data (Eurostat 2014).

Figure 7

Values of indicators for 'Economic viability, profitability' in Hungary compared to the EU average, 2010

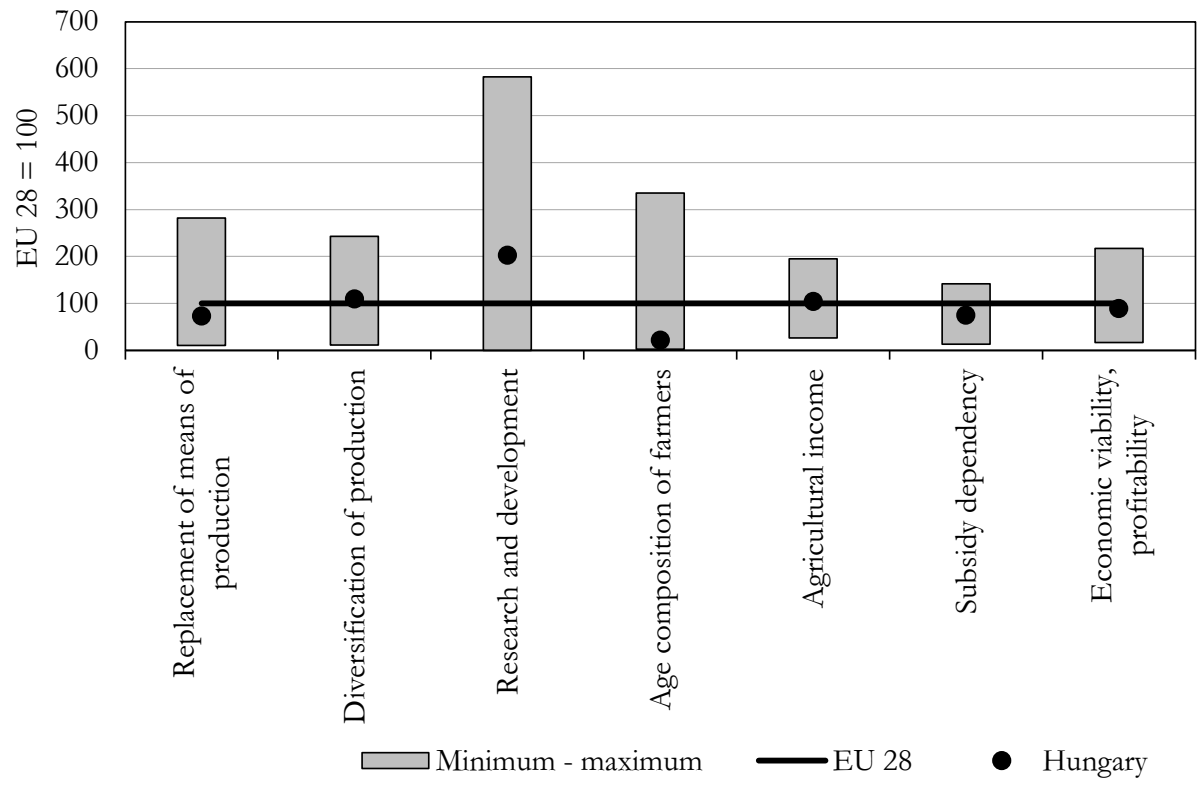

Source: own calculation based on Eurostat data (Eurostat 2014).

Regional Statistics, Vol. 7. No.1. 2017: 179-196; DOI: 10.15196/RS07110 
Hungary fell behind the EU average in terms of the economic dimension of sustainable agriculture according to 2010 figures, a lag rather resulting from the difference in 'Efficiency and competitiveness' than 'Economic viability and profitability' (Figure 8). The position of Hungarian agriculture relative to the EU average showed a slight deterioration in 'Efficiency and competitiveness' between 2000 and 2010, while there was a slight improvement in terms of viability and profitability.

Figure 8

Values of indices for 'Economy' in Hungary compared to the EU average, 2010

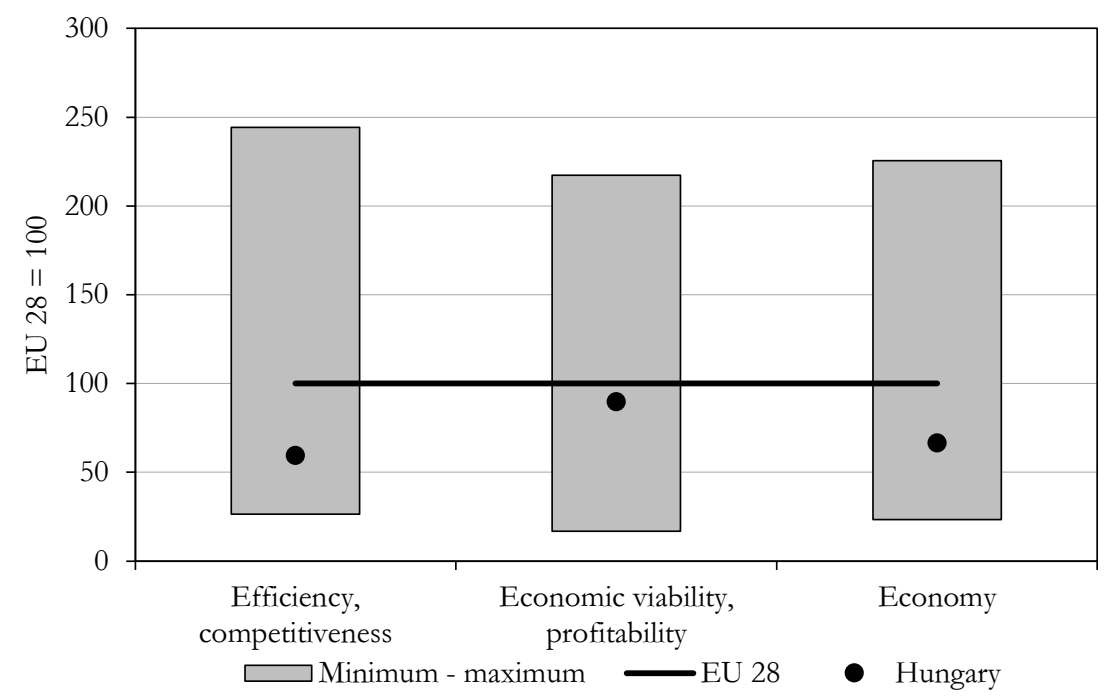

Source: own calculation based on Eurostat data (Eurostat 2014).

Comparisons with regional competitors are shown in Figures 9 and 10. The composite index of 'Economy' grew most for Romanian and Polish agriculture between 2000 and 2010 among the studied countries. The Polish agriculture reached a higher index value in 2010 than the one in Hungary, and caught up with Austria. It is worthwhile noting that the Romanian and Hungarian indices moved mostly together recently. The most significant growth was detected in Romania and Poland between 2000 and 2010, while data for other countries have not changed significantly, apart from the Slovakian index, which experienced growth between 2001 and 2008. 
Figure 9

Indices of 'Economy' for Hungary and the regional competitors, 2000-2010

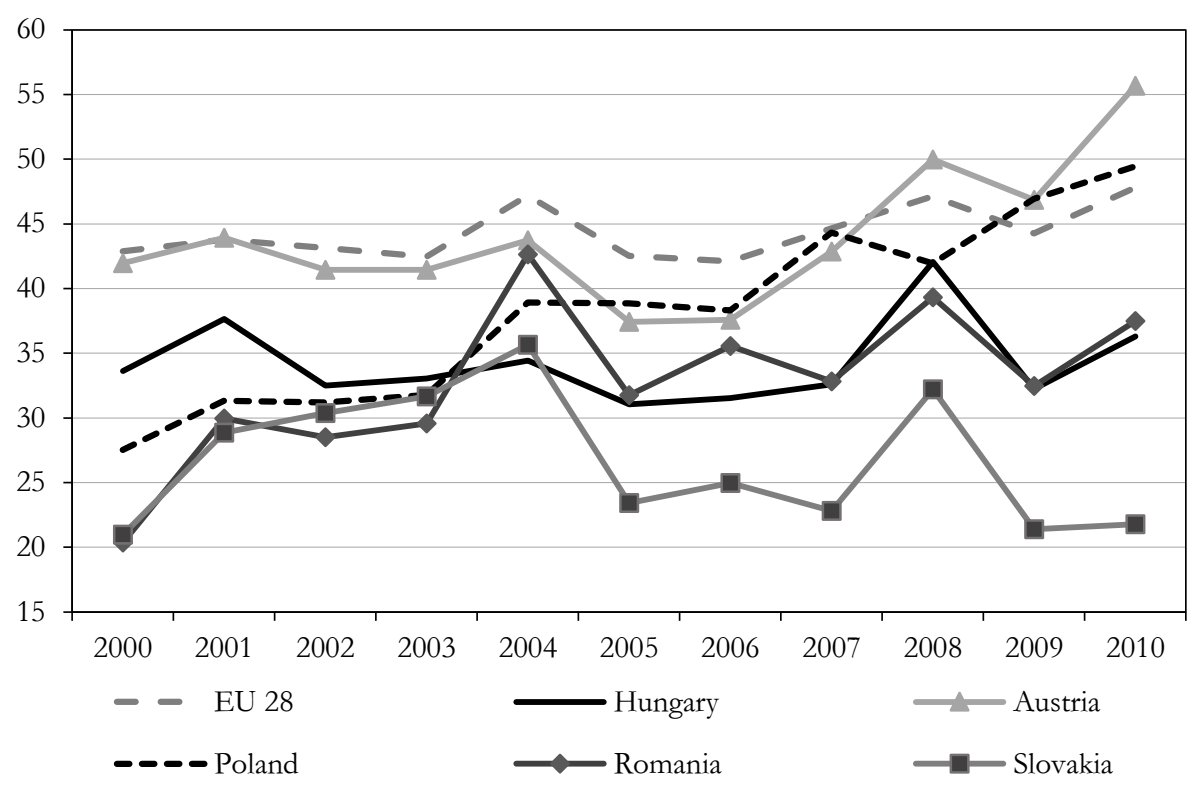

Source: own calculation based on Eurostat data (Eurostat 2014).

Figure 10

Changes of the indices for 'Economy' for Hungary and regional competitors, $2000-2010(2000=100)$

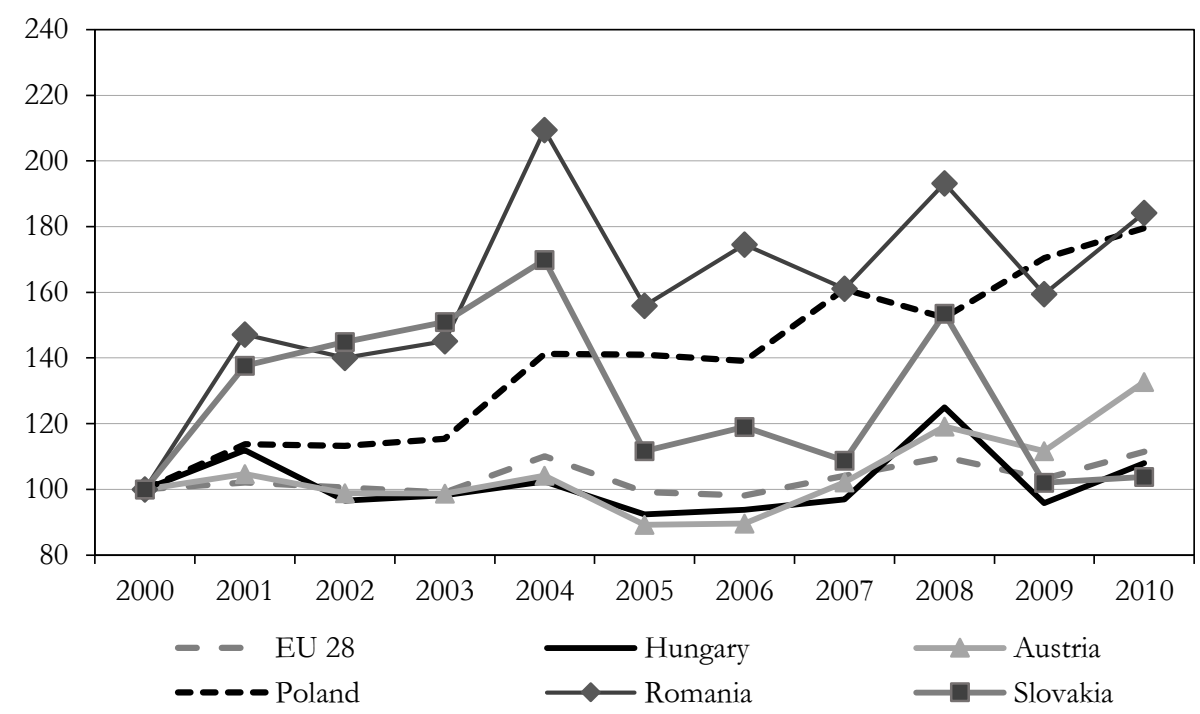

Source: own calculation based on Eurostat data (Eurostat 2014).

Regional Statistics, Vol. 7. No.1. 2017: 179-196; DOI: 10.15196/RS07110 


\section{Discussion - Study limitations}

The quality of the composite indices is influenced by the theoretical coverage of specific areas by relevant indicators supported by adequate quality basic data. For this reason, it is essential to improve the accessibility and quality of basic data for the scientifically sound examination of sustainable agriculture. An additional problem in many areas is long data production time, which also needs improvement. Creating indicators at a lower territorial level is currently not possible in many areas because raw data are not available, a deficiency that could be eliminated by applying proper data collection methodologies or estimation procedures that could enable the dissemination of data at a lower territorial level.

The most important difficulty related to composite indicators is the lack of their widespread acceptance. Their values can be significantly affected by the theoretical framework, scope in the indicator system, and methodology of the weight system essential for their calculation. In many cases, subjective decisions are needed for the development of an indicator system. However, the communication value and role of composite indicators in decision support are indisputable. It is necessary for a composite index that its methodology has appropriate political support, is laid for broad consensus, and is widely accepted.

The system of indicators and the related composite indicators in this research can support European and national agricultural policy decisions, as well as shape the Common Agricultural Policy and its components. They have a good communicating power, since the composites are easy to interpret for the general public. A distinct advantage of the indicator system is that it is suitable for the systemic tracking of changes in agricultural production, both at national and EU levels.

\section{Conclusion}

Based on a literature review, we compiled the definition of sustainability of agriculture, which served as a basis for the development of an indicator system for agriculture sustainability, based on macro data. The data for the indicators have been compiled for the EU member countries for 2000-2012. Based on the indicator system, composite indicators were then developed for the domains of sustainable agriculture. In this study, the domain 'Economy' is analysed using such composite indicators. Spatial and temporal comparisons make it possible to overview the processes in terms of the economic dimension of sustainable agriculture in EU member countries. According to the results, the composite index for 'Economy' had the highest values in the Netherlands and Belgium, while the lowest in Ireland, the Czech Republic, and Slovakia in 2010. The index value increased in the EU by $11 \%$ from 2000 to 2010. Romania, Poland, and Finland had the highest growth rate, while Ireland and Italy had the largest decrease in the EU. Hungary registered a growth rate $(8 \%)$ below the EU average.

Regional Statistics, Vol. 7. No.1. 2017: 179-196; DOI: 10.15196/RS07110 


\section{REFERENCES}

BoOdy, G.-VOndraceK, V.-Andow, D. A.-KrinkE, M.-Westra, J.-Zimmerman, J.WELLE, P. (2005): Multifunctional agriculture in the United States BioScience 55 (1): 27-38.

EU (2012): Sustainable agriculture for the future we want http://ec.europa.eu/agriculture/events/2012/rio-side-event/brochure_en.pdf (downloaded: 15 February 2016)

EUROSTAT (2011): European Statistics Code of Practice Eurostat Publications Office, Luxembourg.

EUROSTAT (2014): Eurostat database http://epp.eurostat.ec.europa.eu/portal/page/ portal/statistics/search_database (downloaded: 15 October 2014)

FARKASNÉ FEKETE, M.-MOLNÁR, J.-SzÜCS, I. (2004): Fenntartható fejlődés és mérési lehetőségei a mezőgazdaságban. In: KOVÁCSNÉ GAÁL, K. (Ed): Agrártermelés harmóniában a természettel XXX. Óvári tudományos napok, 7 October 2004, pp. 1-5. Mosonmagyaróvár.

FEHER, I.-BEKE LISANYI, J. (2013): Approaches to sustainability in the agricultural policy Economics and Rural Development 9 (2): 7-15.

FEKETE-FARKAS, M.-VALKÓ, G.-TÓTH, R. (2011): Global challenges and biofuels International Journal of Social Sciences and Humanity Studies 3 (1): 227-236.

Huang, J.-Tichit, M.-Poulot, M.-Darly, S.-Li, S.-Petit, C.-Aubry, C. (2015): Comparative review of multifunctionality and ecosystem services in sustainable agriculture Journal of Environmental Management 149 (1): 138-147.

INEA (2002): The Sustainability of Italian Agriculture: A Set of Indicators Paper prepared by Ms Velazquez for the 8th IWG. AGRI Seminar Paris, 21-22 November 2002

Kirchmann, H.-Thorvaldsson, G. (2000): Challenging targets for future agriculture European Journal of Agronomy 12 (1): 145-161.

KOVÁCS, I. (2016): The effects of corporate social responsibility on consumer decisions in Hungary Vadyba Journal of Management 29 (2): 27-34.

KRÓlCZYK, J. B.-LATAWIEC, A. E.-KuBOŃ, M. (2014): Sustainable agriculture - the potential to increase wheat and rapeseed yields in Poland Polish Journal of Environmental Studies 23 (3): 663-672.

MAFF (2000): Towards Sustainable Agriculture - A Pilot Set of Indicators Maff Publications, London.

National Research Council (2010): Toward Sustainable Agricultural Systems in the 21st Century The National Academies Press, Washington D. C.

OECD (2001): Multifunctionality: towards an Analytical Framework OECD Publications, Paris.

OECD (2008): Handbook on Constructing Composite Indicators - Methodology and User Guide OECD Publications, Paris.

OECD (2012): Quality framework and guidelines for OECD statistical activities Version 2011/1, STD/QFS(2011)1, OECD Statistics Directorate, Paris.

PopP, J.-LAKNER, Z.-HARANGI-RÁKOS, M.-FÁRI, M. (2014): The effect of bioenergy expansion: Food, energy, and environment Renewable and sustainable energy reviews 32 (1): 559-578.

Regional Statistics, Vol. 7. No.1. 2017: 179-196; DOI: 10.15196/RS07110 
RISE (2016): Response-Inducing Sustainability Evaluation http://www.hafl.bfh.ch /index.php?id=1472\&L=1 (downloaded: 13 February 2016)

Rossing, W. A. H.-Zander, P.-Josien, E.-Groot, J. C. J.-Meyer, B. C.-Knierim, A. (2007): Integrative modelling approaches for analysis of impact of multifunctional agriculture: A review for France, Germany and The Netherlands Agriculture, Ecosystems and Environment 120 (1): 41-57.

SARE (1997): What is sustainable agriculture? Sustainable Agriculture Research and Education http:/ /www.sare.org/Learning-Center/SARE-Program-Materials/NationalProgram-Materials/What-is-Sustainable-Agriculture (downloaded: 10 February 2016)

Smith, C. S.-MCDONALD, G. T. (1998): Assessing the sustainability of agriculture at the planning stage Journal of Environmental Management 52 (1): 15-37.

TAKÁCSNÉ GYÖRGY, K.-TAKÁCS, E.-TAKÁCS, I. (2008): Az agrárgazdaság fenntarthatóságának mikro- és makrogazdasági dilemmái In: MÉZES, M. et al. (Eds): Bulletin of the Szent István University, Special Issue pp. 341-352. Szent István University, Gödöllő.

USDA (1999): Sustainable agriculture: definitions and terms. Special reference briefs No. SRB 99-02. U.S. Department of Agriculture http://www.nal.usda.gov/ afsic/pubs/terms/srb9902.shtml (downloaded: 8 February 2016)

VALKÓ, G. (2015): A fenntartható mezógazdaság indikátorrendszerének kialakítása kompozit indikátorok Doctoral Dissertation at Szent István University, Doctoral School of Management and Business Administration, Gödöllő.

VALKÓ, G.-FEKETE-FARKAS, M. (2014): Measurement of Sustainability of Agriculture In: UgrósDy, Gy.-MolnÁr, J.-SZÜCS, I. (Eds): The Evaluation of Natural Resources pp. 196-205., Agroinform Publishing and Printing Ltd, Budapest.

van Cauwenbergh, N.-Biala，K.-Bielders，C.-Brouckaert，V.-FranCHOis，L.Garcia Cidad, V.-Hermy, M.-MAthijs, E.-Muys, B.-Reijnders, J.SAUVEnier, X.-YAlckX, J.-VANCloOster, M.-VAN Der VeKen, B.WAUters, E.-PEETERS, A. (2007): SAFE - A hierarchical framework for assessing the sustainability of agricultural systems Agriculture, Ecosystems and Environment 120 (2-4): 229-242.

Regional Statistics, Vol. 7. No.1. 2017: 179-196; DOI: 10.15196/RS07110 